Arhe XVI, 32/2019

UDK 2:17 Jašar S.

DOI https://doi.org/10.19090/arhe.2019.32.275-294

Originalni naučni rad

Original Scientific Article

SAMIR BEGLEROVIĆ ${ }^{1}$

Univerzitet u Sarajevu, Fakultet islamskih nauka

ORHAN JAŠIĆ ${ }^{2}$

Univerzitet u Sarajevu, Fakultet islamskih nauka / Univerzitet u

Tuzli, Filozofski fakultet

\title{
TEOLOŠKO-MORALNE I BIOETIČKE TEME U DJELU „RAZGOVOR SA SVRAKOM“ SELIMA SAMIJA JAŠARA
}

Sažetak: U prvom dijelu rada ukratko je predstavljen životni put teologa, sufije i muderrisa (profesora) Selima Samija Jašara iz Vučitrna (Kosovo). Iako je napisao nekoliko dijela iz teologije, u ovome radu osvrnuli smo se na veoma zanimljivo kazivanje Razgovor sa svrakom, koje je na naš jezik preveo profesor Fejzulah Hadžibajrić. U tome tekstu u formi dijaloga derviš (u ovome slučaju sam autor Selim Sami Jašar) razgovara sa svrakom, prvenstveno o temama iz tașawwufa (sufizam) i dogmatike ('aqā'id), ali i teologije morala ('ilm $a l-a \underline{h l} \bar{a} q$ ). Posebnu pažnju privlači prezentiranje simbolike animalnoga svijeta, biosa, čija se esencija oslovljava upravo iz spomenutih perspektiva. U tekstu je, pored ostaloga, oslovljen i historijski kontekst nastanka poslanice, za nas posebno značajan budući da je napisana u prvoj polovini dvadesetoga stoljeća, u periodu u kojem se u literaturi objavljenoj na Zapadu nije posvećivala velika pažnja zooetičkim i fitoetičkim problemima. Po našem mišljenju, upravo ovaj podatak čini poslanicu posebno zanimljivom.

Ključne riječi: Selim Jašar, tașawwuf, sufizam, teologija morala,'ilm al-ahlāa, svraka, etika

\footnotetext{
${ }^{1}$ E-mail adresa autora: samir.beglerovic@ fin.unsa.ba

${ }^{2}$ E-mail adrese autora: orhan.jasic@fin.unsa.ba / orhanjasic@yahoo.com
} 


\section{UVOD}

Poslanica „Razgovor sa svrakom“, kao i sâm njen autor Selim Sami Jašar, posebno su interesantni i važni, i to iz nekoliko razloga. Prije svega, autor je, kako ćemo kasnije vidjeti, iako krajnje originalan i plodonosan pisac, ipak u znatnoj mjeri nepoznat, ne toliko kao duhovni učitelj koliko u aspektu njegovih djela odnosno neskrivene potentnosti za precizno izražavanje duhovnih stanja i, uopće, duhovnog iskustva. I u svome djelovanju kroz tașawwufsku praksu - țarīqa (dosl. „,duhovni put"), iza Jašara je ostalo tek nekoliko učenika koji su, koliko je to uopće objektivno moguće ustvrditi, u punini uspjeli nastaviti njegov odgojni i sufijsko-teološki rad. Tako je na prostoru Bosne i Hercegovine djelovao Fejzulah Hadžibajrić, koji je učenje Selima Samija dalje transponirao snagom vlastitog genija unutar tadašnjeg vjersko-kulturnog života Bosne, izražavajući ga u različitim formama: vjersko-teološkoj, obrazovnoj, društveno-političkoj, stručno-administrativnoj i sl. ${ }^{3}$ Skoro da nije bilo nijednog javnog ili privatnog obraćanja Hadžibajrića na kojem se, izražavajući sada vlastite ideje, nije pozivao na učenje i autoritet Jašara.

S druge strane, djelo „Razgovor sa svrakom“ predstavlja, čini se, unikatan sadržaj, kada je riječ o tașawwufsko-teološkim, te filozofskim djelima bosanskih autora. Sâmo izlaganje, doslovno - Jašarev razgovor sa pticom, svrakom, po sebi pobuđuje pažnju. Odatle i brojni, doduše mahom usmeni, komentari, koji su problematizirali narav toga iskustva: krajnje alegorijska, iskustveno-imaginativna ili, pak, što je polazište mutesavvifa, zbiljska. Nadalje, dijalog, uslijed fascinacije sadržajem ponovit ćemo: čovjeka i ptice, i u svome izvedenom, značenjskom smislu nudi brojne aspekte koje vrijedi analizirati, kako onaj sufijski, tako i teološki te, napose, teološko-moralni, što je i zadatak našega teksta. No, prije negoli izložimo bilo kakvu analizu „Razgovora sa svrakom“, ukratko ćemo se u nastavku rada osvrnuti na značajnije segmente iz života Selima Samija Jašara.

${ }^{3}$ Usp. Samir Beglerović, Tesavvuf Bosne u vidicima Fejzulaha Hadžibajrića: Vjerski i kulturni razvoj bosanskih muslimana u prvoj polovini XX stoljeća, Sarajevo, „Bookline“, 2014., str. 86-96. 


\section{UČITELJ IZ VUČITRNA SELIM SAMI JAŠAR}

O Selimu Samiju Jašaru ne postoji mnogo podataka na bosanskom jeziku. ${ }^{4} \mathrm{Na}$ osnovu dostupnih informacija poznato je da se rodio u Vučitrnu u izuzetno religioznoj učiteljskoj obitelji najvjerojatnije krajem devetnaestoga stoljeća. U rodnome mjestu završio je osnovno obrazovanje, dok je daljnje studije nastavio u Prištini i Istanbulu.

Vjersko-teološko obrazovanje $u$ to vrijeme uglavnom je podrazumijevalo odlazak na muslimanski Istok, odnosno iskustvo izravnoga učenja (slušanja, izlaganja te polaganja predmeta) pred muderissima i šejhovima. Oni su svojim studentima prenosili znanje putem specifičnog sustava halke, koji je, pored ostaloga, podrazumijevao, $\mathrm{s}$ jedne strane, manji broj učenika, te, pored toga, razvijanje posebne duhovne i emotivne bliskosti između učitelja i učenika. ${ }^{5} \mathrm{Na}$ ovaj način, a slijedeći rani muslimanski institucionalni oblik poduke, zadaća učitelja je prvenstveno bila odgojne naravi (odatle i naziv „murabbī“ za učitelja, doslovno „onaj koji odgaja radi Gospodara“). Među najznačajnijim profesorima kod kojih je Selim Sami Jašar stjecao znanje ubrajaju se Mehmed Sezai efendija iz Prištine te Dagistani 'Abd al-Qādir. Nakon završenoga teološkoga studija u Istanbulu, za kojeg ne znamo koliko je

${ }^{4}$ Do sada su na našemu jeziku objavljeni slijedeći tekstovi o Selimu Samiju Jašaru: Fejzulah Hadžibajrić, O autoru Tuhfe, u: Selim Sami Jašar, Tuhfa - Dar , Vatan, Malmö, 1996., str. 5-6., Sead Halilagić, „Hadži Selim Sami ef. (Uz 40godišnjicu smrti)“, Šebi arus, Sarajevo 91. Amir Orman, „Pedeset godina od preseljenja šejh hadži Selim Sami jašara“ Šebi arus, Sarajevo 2000., str. 115. Samir Beglerović, „Crtice iz života hadži šejha Fejzulaha efendije Hadžibajrića“, u: Znakovi vremena, svezak 7, br. 25, 2004, str. 18. S. Beglerović, Tesavvuf Bosne u vidicima Fejzulaha Hadžibajrića: Vjerski $i$ kulturni razvoj bosanskih muslimana u prvoj polovini XX stoljeća, str. 86-96.

5 Sustav halke je tradicionalni muslimanski način obrazovanja u komu je profesor (šejh) predavao i istovremeno odgajao svoje učenike u ciklusima od, najčešće, četiri, osam ili dvanaest godina. Učenici su bili pozicionirani sjedeći u krugu unutar kojeg je bio i učitelj. Ovaj način školovanja je bio pretežito zastupljen u Osmanskoj imperiji, a i danas je moguć susret s ovom vrstom izobrazbe u muslimanskim državama Istoka. 
trajao, vraća se u Vučitrn. ${ }^{6} \mathrm{U}$ međuvremenu postaje i pripadnik tașawwufskog ${ }^{7}$ odnosno derviškog (lat. sufijskog) qadariyskoga țariqāta ${ }^{8}$, pristupajući tome redu pred učiteljem hazreti (poštovani) Muhammadom Amīnom Sulaymānījem al-Barzanğījem, tijekom njegovog boravka na balkanskom podneblju, preciznije, u Skoplju.

Pošto je Jašarev rodni Balkan veoma često u historiji bio sjecište brojnih ratova, dogodilo se da je u svojoj mladosti za vrijeme Balkanskih ratova zajedno sa svojim ocem boravio u zarobljeništvu. Nažalost, ovom prilikom ne možemo točno precizirati u kojoj situaciji su otac i sin bili zarobljeni, no, poznato je da je nakon Prvog svjetskog rata otpočeo predavati teološke predmete $u$ Ali-begovoj medresi u Vučitrnu, a njegova znanstvena specijalnost bila je muslimansko religijsko nasljedno pravo (ar. farā'iḍ).

Selim Sami Jašar poznavao je arapski, perzijski i turski jezik, $s$ tim da nije govorio bosanski (srpskohrvatski) jezik mada ga je razumio. Svoje radove objavljivao je primarno na turskome jeziku, najčešće $u$ novinama "Hak", "Išik", i "Dogru yol" koje su izdavane u razdoblju između dva svjetska rata u Skoplju. Kada su u pitanju njegova pisana

${ }^{6} \mathrm{U}$ posljednje vrijeme, postoje najave jednog ozbiljnijeg, sâmim time i detaljnijeg, studiranja života i djela Selima Samija Jašara. Tako je, po našim saznanjima, u Republici Turskoj prijavljena doktorska teza koja upravo podrazumijeva realiziranje toga zadatka. Relevantna ocjena ozbiljnosti toga pristupa može se donijeti na osnovu objavljenoga teksta: „Yüyılda Yunus'un İzinde Bir Kādırî Mürşidi: Şeyh Seliım Sâmi Efendi“, u zborniku: Balkanlarda İrfan Ocakları: Bosna'da Kädirîlik, ur. Ahmet Ögke, Antalija, Yurtdışı Türkler, 2019., str. 127-134.

${ }^{7}$ Tașawwuf (latinizirana forma je sufizam) jest osobita vrsta duhovnoga odgoja u tradiciji muslimana. U tome procesu polaznik koji se odgaja prolazi stazom duhovnog viteštva (sayr as-suluk), a temeljni zadatak jest približiti se dragome Bogu (ar. qurb), konstantnim svjedočenjem vjerovanja u Boga Jednog i Jedinog, pročišćenjem duše odnosno činjenjem dobra. Pripadnici tașawwufa nazivaju se derviši ili sufije. (Usp. Rešid Hafizović, Temeljni tokovi sufizma, 'Bemust', Zenica, 1999., str. 5-15.)

${ }^{8}$ Tarīqah (put) jest, zapravo, put u, uslovno rečeno, ,redovničkoj“ zajednici sljedbenika tașawwufa. U muslimanskoj tradiciji poznato je egzistiranje dvanaest priznatih redova, ali ćemo se u ovome radu najviše orijentirati prema qadariyskome redu, iz razloga što je Selim Sami Jašir bio pripadnik toga țarīqata. 
djela, napomenut ćemo da je Jašar napisao desetak djela iz različitih teoloških oblasti, od polja obredoslovlja (ar. 'ibādah) i tumačenja Kur'ana ( tafsīr) do religiozne književnosti, koja je za nas u ovome članku izuzetno značajna budući da ćemo posebnu pažnju u nastavku rada posvetiti jednome od njenih segmenata.

Pred kraj života, tj. nakon Drugog svjetskog rata obolio je od Parkinsonove bolesti. Umro je drugog studenoga 1951. godine, a pokopan je na gradskome mezarju (groblju) u Vučitrnu.

Osim svojih redovitih učenika u medresi u Vučitrnu odgajao je i podučavao trojicu duhovnih učenika (ar. murida); dvojicu sa Kosova hafiza ${ }^{9}$ Fahri ef. Iljazija ${ }^{10}$ i hafiza Sabita efendiju Zaima ${ }^{11}$, te jednoga iz Sarajeva, ranije spomenutog Fejzulaha Hadžibajrića ${ }^{12}$, koji je, što je

${ }^{9}$ Hafiz je osoba koja je memorizirala cijeli Kur'an.

${ }^{10}$ Fahri ef. Iljazi (1903-1985.) rodio se u izuzetno religioznoj učiteljskoj obitelji u Đakovici na Kosovu. Formalno religijsko obrazovanje stekao je u rodnome mjestu i Prizrenu gdje stječe i gradus muderrisa. Sa jedanaest godina je postao hafiz. Bio je na funkciji vjerskog službenika (imam) u nekoliko džamija, a kasnije je bio i muftija za oblast Peći. Također je osamnaest godina predavao u medresi u Đakovici. Posebno se bavio istraživanjem u polju 'Ilm al-Kalama, filozofije i tașawwufa, te je, pored toga, odlično poznavao i muslimansku jurisprudenciju (ar. fiqh). Iznimno je bio upućen u teologiju klasičnog muslimanskoga autora Ibn 'Arabīja. Napisao je nekoliko djela na albanskome jeziku od kojih se posebno ističu Ilmihal, Mevlud i Vehbije. Umro je 1985. godine i ukopan je na groblju u Đakovici.

${ }_{11}$ Hafiz Sabit ef. Zaim rođen je u Vučitrnu 1893. godine. Potjecao je iz religiozne obitelji. Osnovno i srednje obrazovanje stekao je u rodnome mjestu dok je teološki studij završio u Istanbulu. Poslije povratka iz Turske nastavio je svoje duhovno izgrađivanje, tj. duhovni odgoj i školovanje kod Selima Samija Jašara. Paralelno je bio i na funkciji imama u Čarci džamiji u Vučitrnu. Pored toga bio je poznati vaiz (propovjednik), a u vjerskim strukturama Islamske vjerske zajednice u Jugoslaviji obavljao je nekoliko značajnih funkcija, od kojih je važno istaći članstvo u Vrhovnom saboru Islamske vjerske zajednice u SFRJ. Umro je 1975. godine, a ukopan je na gradskome groblju u Vučitrnu pored svoga učitelja Selima Samija Jašara (Usp. Ferhat Grguri, „Hadži hafiz Sabit Zaimi efendi“, u: Glasnik Vrhovnog islamskog starješinstva u Socijalističkoj Federativnoj Republici Jugoslaviji, svezak 6, br. 39,1976., str. 702).

12 Fejzulah Hadžibajrić (1913-1989.) je bio ekspert u oblasti tașawwufa. Osnovno obrazovanje je stekao u Sarajevu nakon kojeg je maturirao na Gazi Husrev-begovoj medresi u istome gradu. Poslije srednje škole okončao je viši 
također važno, znatan dio Jašarevih djela prevodio na bosanski jezik. Kao što je prethodno kazano, Selim Sami Jašar bio je ekspert za religijsko nasljedno pravo, ali pored toga njegov duhovni put ga je vodio i u oblast, uslovno kazano, „ekstatičke teologije otkrovenja“. Želeći ovo pitanje tek otvoriti, akcentiramo da se osobenost znanstvenog opusa Selima Samija ${ }^{13}$ naročito ogleda $\mathrm{u}$ činjenici da je u njemu primjetna svojevrsna interpretacija spomenute metode „,iskustvene i ekstatične teologije otkrovenja“ (ar. kašf). Ova vrsta iskustvene teologije, barem kada je riječ o muslimanskoj tradiciji, podrazumijeva, prvo, onu dimenziju vremena, trajanja, koja nije egzistent po sebi već predstavlja promjenu u spoznajnom iskustvu osobe realiziranu uslijed časovite komunikacije te osobe sa Istinom (haqiqah), i, drugo, na njoj se temelji vjerovanje te osobe, drugim riječima, tek $\mathrm{s}$ time se postiže punina muslimanskoga simbola vjerovanja - šehādeta, doslovno svjedočenja. Sukladno tome se može govoriti o otkrovenju kao o vrsti „izravne spoznaje“ (ar. mubāšarah). Za razliku od aristotelijanskog razumijevanja nekih muslimanskih filozofa, te, uslovno rečeno, „službenog“ atomističkog koncepta vremena promoviranog učenjem poznat teologa Abū al-Ḥasana al-Aš'arīja (u. 935./936. godine), znatan broj mutașawwifa u svojim radovima opredijelio se za takav koncept vremena, koji je podrazumijevao njegovo razumijevanje kao protoka svjesnosti uma koji

studij teologije (,Alijja“), stekavši diplomu kod profesorom 'aqā'ida (dogmatike) Ahmeda Bureka. Između dva svjetska rata radio je kao vjeroučitelj u nekoliko sarajevskih škola. Poslije Drugog svjetskog rata završio je i studij Orijentalne filologije Filozofskog fakulteta Univerziteta u Sarajevu u prvoj generaciji svršenika. Preveo je i komentirao prva dva toma Matnawijje autora Ğalāl ad-Dīn Rūmīja s perzijskog jezika. Načinio je brojne prijevode sa arapskoga jezika te je pisao o tașawwufu. Bio je i muršid ili šayh (duhovni odgajatelj i vodič). (Usp. Samir Beglerović, „Crtice iz života hadži šejha Fejzulaha efendije Hadžibajrića“, u: Znakovi vremena, svezak 7, br. 25, 2004., str. 10-38)

${ }^{13}$ Selim Sami Jašar napisao je slijedeće uratke s tim da nisu svi publicirani: 1. Komentar sure Jasin, 2. Komentar sure Rahman, 3. Komentar Evradi-šerifa; 4. Menakibi Abdul-Kadir Gejlani (biografija i doživljaji Abdul-Kadira Gejlanije); 5. Tuhfe; 6. Sanihat - tarikatske crtice; 7. Dva odgovora; 8. Zbirka ilahija 9. Razgovor sa svrakom. (Usp. Fejzulah Hadžibajrić, „O autoru Tuhfe“, u: Selim Sami Jašar, Tuhfa - Dar -, Vatan, Malmö, 1996., str. 6.) 
promišlja i koji je, time, nezavisan od fizičkog kretanja. ${ }^{14}$ Predoči li se vrijeme u svojoj punini, kao vrsta kružnice, onda svaka tačka na njoj predstavlja ono „sada“ ( $\bar{a} n)$ i sâmim time dio je protežućeg vremena kao takvog. Štaviše, preko toga „sada“, osoba jedino i može biti, zapravo tada ona to i jeste: spoj ili veza (nisba) sadašnjosti sa vječnošću. ${ }^{15}$ Ovako izložen, koncept razumijevanja vremena uveliko nalikuje Plotinovoj interpretaciji, $\mathrm{i}$ to njegovog određenja vremena kao onoga što nije kretanje $^{16}$, i što nije izvan duše već je upravo u njoj i sa njom. ${ }^{17}$ Namjerno smo spomenuli Plotina budući da je njegovu interpretaciju, naravno, izraženu u jednom sasvim drugačijem kontekstu, moguće prepoznati u originalnim odmišljanjima jednoga od najpoznatijih tașawwufskih autora Ibn 'Arabīja (u. 1240. godine) što je, sasvim zasigurno, postalo jedna od karakteristika Jašarevog učenja, manifestirana i u djelima njegovih učenika.

Uobičajena klasična definicija vremena (waqt), data u leksikonu poznatog 'Abd al-Qāhir al-Ğurğānīja (1078.), vrijeme predstavlja kao izraz za (duhovno) stanje osobe utemeljeno na njenoj općoj pripravnosti (isti 'dād), nešto što nije izvanjski stvoreno ( $\dot{g} a y r ~ m a \breve{g} ' \bar{u} l) .{ }^{18}$ Također, interpretirajući spomenutog Ibn 'Arabīja, al-Ğurğānī će na drugom mjestu vrijeme definirati kao izraz za duhovno stanje osobe unutar vremenskog perioda duhovnog stanja kao takvog (zamān al-hāal), koje nije vezano niti za prošlost niti za budućnost. ${ }^{19}$ Konačno, ovaj spoj Plotinovog i Ibn 'Arabījevog učenja zastupljenog kod Selima Samija

\footnotetext{
${ }^{14}$ Usp. veoma zanimljivu studiju: Gerhard Böwering, „,The Concept of Time in Islam“, u: Proceedings of the American Philosophical Society, svezak 141, br. 1, 1997., str. 59-60.

${ }^{15}$ Usp. Mohamed Haj Yousuf, Ibn 'Arabî - Time and Cosmology, London - New York, Routledge, 2008., str. 47-48.

${ }^{16}$ Usp. Plotin, Eneade, Beograd, NIRO „Književne novine“, 1984., III.7.-8., str. 102-105.

${ }^{17}$ Ibid., III.11.60., str. 110.

18 Al-Ğurğān̄ī, Kitāb at-ta'rīfāt, u zbirci poslanica: Mağmū'a al-kutub, objavljenoj u Kairu, al-mațba'a al-ḥamīdiyy al-mișriyya, 1321. god. po Hidžri, str. 175 .

${ }^{19}$ Al-Ğurğānī, Iștilāhāàt aṣ-ṣūfiyya al-wārida fì al-Futūhāt al-makkiyya, Ibid., str. 2 .
} 
Jašara možda se najjasnije vidi u djelima Fejzulaha Hadžibajrića. Naime, zadržavajući se na razumijevanju kategorije vremena, tek taj primjer da uzmemo, Hadžibajrić će ponuditi vlastitu definiciju, naravno, duboko nijansiranu Plotinom i Ibn 'Arabījem. Po njemu, vrijeme (waqt) je „ljudsko stanje u vremenu koje nije prošlo, vrijeme u kome se sufi nalazi; pojava istinitosti Istine preko otkrovljenja (otkrića)““. ${ }^{20}$

Vraćajući se, opet, na Ibn 'Arabīja, u svome zasigurno najobimnijem i jednom od najznačajnijih djela: „Mekkanska otvaranja“ (al-futūhāt al-makkiyya), pored ostalih, posebno je obradio pitanje onoga što je oslovio „kružnim odnosom“ (nasab dawriyya) između ontoloških uzroka bîtka. Na sâmome početku taj ontološki odnos predstavio je kružnim dijagramom, naglašavajući kružni tok međusobne povezanosti: Božanskih odnosâ i stanjâ, stanjâ i vremenâ, vremenâ i kretanjâ, kretanjâ i obzorâ, obzorâ i namjerâ, namjerâ i manifestiranja, manifestiranja i vjerozakonâ (šeră'i ), te vjerozakonâ i Božanskih odnosâ, što se, potom, nastavlja istim redom, budući da kružnica ne sadrži kraj. ${ }^{21}$ Svaka namjera ima sasvim konkretan obzor, štaviše, svako konkretno manifestiranje je, time, i potpuno originalno te, logično, neponovljivo. S obzirom da bîtak konstantno egzistira, Ibn 'Arabī to oslovljava „Božansko proširivanje“ (ittis $\bar{a}^{\prime}$ ilāhà) s obzirom na ontološku uzročnost Božanskih odnosâ i manifestiranjâ, svaki njegov segment nastavlja opstojati Božijim podržavanjem (quyūmāt), a istodobno mu se konstantno priključuju nove čestice. ${ }^{22}$ Naprosto, događa se „konstantno stvaranje“ (halq ğadīd, creatio continua), a već u Kur'anu se naglašava da većina ljudi to ne može spoznati. ${ }^{23}$ Ovakva Ibn 'Arabījeva interpretacija kur'anskog teksta temeljno je razvijena iz posljednje Božije Objave, otuda i insistiranje na

${ }^{20}$ Fejzulah Hadžibajrić, „Mali rječnik sufijsko-tarikatskih izraza“, u: Mustafa Cerić (ur.), Teșawwuf, islamska mistika, Zbornik radova Prvog simpozija 1408./1988., Zagreb, Zagrebačka džamija, 1989., str. 215.

${ }^{21}$ Ibn 'Arabī, al-Futūhāt al-makkiyya, Bejrut, Dār al-kutub al-'ilmiyya, 1998., poglavlje 48., cjelina: „Mas'ala dawriyya min hādā al-bāb wa hādihi șūretuhā, tom I, str. 334.

${ }^{22}$ Ibid., str. 335.

${ }^{23}$ „Pa zar smo prilikom prvog stvaranja malaksali? Ne, ali oni u konstantno stvaranje sumnjaju.“ (Kur'an, 50:15) 
pojmu stvaranja, no, s druge strane, ostavlja dovoljno mjesta i za neoplatonička učenja budući da se konstantno stvaranje može razumijeti i kao osnova ili vid emanacije na kojoj je insistirao Plotin. ${ }^{24}$

Imajući sve prethodno rečeno $\mathrm{u}$ vidu, jasno je porijeklo $\mathrm{u}$ uvodu spomenute dvojbe u vezi sa porijeklom sadržaja „Razgovara sa svrakom“. U ovakvom kontekstu shvaćeno, moguće je razgovor shvatiti ne samo kao alegoriju već i kao posljedicu izravnoga odnosa prema Istinitosti, manifestiranu u susretu dvaju vrsta, u ovome slučaju, čovjeka i životinje, Selima Samija Jašara i svrake. Naprosto, izravan odnos Jašara sa Istinom, realiziran u jednom vremenskom trenu, hipu, manifestiran je i kroz spoznaju egzistencije ptice, odnosno, konkretnije, svrake. Imajući u vidu da je jedini metod transponiranja metafizičkih principa u osjetilne forme, upotreba simbola ili alegorije, Selim Sami je neke od darovanih spoznaja izrazio upravo alegorijski, zadržavajući time i zbilju i alegoriju u svojim riječima.

Sadržaj poslanice posebno ćemo izložiti u slijedećem poglavlju.

\section{SADRŽAJ POSLANICE RAZGOVOR SA SVRAKOM}

Egzaktno vrijeme nastanka traktata Razgovor sa Svrakom teško je utvrditi. Pretpostavljamo da je napisan u periodu prije Drugog svjetskog rata. Kao i ostala djela Selima Samija, i ovu kratku alegorijsku poslanicu na bosanski jezik preveo je Fejzulah Hadžibajrić, a prvi put je štampana u Zagrebu koncem osamdesetih godina prošloga stoljeća. ${ }^{25}$ Kako smo rekli, po svome sadržaju može se svrstati istodobno i u polje religiozne književnosti, ali i vjersko-teološke sa izraženim segmentima ekstatične teologije (kašf). Jednako tako, budući da je u tekstu prezentiran dijalog derviša (sâm Selim Sami Jašar) i svrake, poslanica svojom dijaloškom

${ }^{24}$ Usp. zanimljivu studiju: Brandon Zimmerman, „Does Plotinus present a Philosophical Account of Creation?", u: The Review of Metaphysics, sveska 67, br. 1, septembar 2013., str. 55-105.

${ }^{25}$ Usp. Selim Sami Jašar, „Razgovor sa svrakom“, prema Fejzulah Hadžibajrić, „Zikr i iršad“, u: Mustafa Cerić (ur.), Tesawwuf, islamska mistika, Zagrebačka džamija, Zagreb, 1989., str. 158-161. 
formom pomalo podsjeća i na klasična filozofska djela poput određenih Platonovih dijaloga. ${ }^{26}$

Sama radnja poslanice zbiva se pored tekije ${ }^{27}$ gdje je sjedio derviš, a u njegovu blizinu ubrzo slijeće i svraka. Nakon pozdrava mira (ar. selamun alejkum) kojeg upućuje ptica i derviševog odgovora istom porukom (ar. ve alejkumu selam) počinje i njihova konverzacija.

$\mathrm{U}$ prvome dijelu poslanice predmet njihovog razgovora jest jedan za ljudski rod poseban događaj iz svete povijesti. Riječ je o grijehu blagoslovljenoga poslanika Ādama u Raju (ar. ğannat), tj. njegovom konzumiranju plodova sa zabranjenog stabla, ali i o pokajanju zbog učinjenog prijestupa odnosno neposluha prema Bogu.

Zatim u nastavku teksta, a u obliku odgovora na druga derviševa pitanja, ptica simboličkim iskazom opisuje vrijednost crne i bijele boje, ali i pojma „pravoga puta“. Uz to su navedena i dva vrlo značajna tașawwufska termina: $\operatorname{fana}^{28} \mathrm{i}$ baq $\bar{a}^{29}$. U ovome diskursu svraka izdvaja i posebnu skupinu religioznih ljudi koji su, supstancijalno motrivši, neznalice, te ih imenuje „dervišima neznalicama“. Pored spomenutih tema u njenim odgovorima opisno se „dočaravaju“ i dogmatsko-moralni pojmovi grijeha, vrijednosti znanja ('ilma) i Svevišnosti, a prije toga i narav qadariyskoga tarīqata. Također se da primijetiti, tom prilikom, i blagi element, uslovno kazano suvremenim pojmovljem -,,fitoetičke

${ }^{26}$ Često su Platonove teorije dovođene u vezu sa religijom i ritualima. Vidi npr. jednu stariju studiju: William H. Desmonde, „The Ritual Origin of Plato's Dialogues: A Study of Argumentation and Conversation among Intellectuals", American Imago, sveska 17, br. 4, zima 1960., str. 389-406.

${ }^{27}$ Tekija je jedna vrsta samostana u kome obitavaju pripadnici tarīqata to jest derviši ili sufije. U tome objektu najčešće provode vrijeme u različitim obredima i molitvama, ali i u karitativnome djelovanju. Usp. Fehim Nametak, Pojmovnik divanske $i$ tesavvufske književnosti, Orijentalni institut u Sarajevu, Sarajevo, 2007., str. 243.

${ }^{28} F a n \bar{a}^{\prime}$ je „duhovno nestajanje, iščeznuće i utapanje u Božija svojstva“. (Fejzulah Hadžibajrić, Mali rječnik sufijsko-tarikatskih izraza, str. 187.)

${ }^{29} B a q \bar{a}^{\prime}$ to je ono što je vječno. (Usp. F. Hadžibajrić, Mali rječnik sufijskotarikatskih izraza, str. 182.) 
svijesti، ${ }^{30}$, zbog toga što svraka iznosi mišljenje prema kojemu je biljni svijet, točnije drveće, znatno bolji dom pošto je ,građevina svemilosnog Boga“, te se analogno tome može razumjeti i da su na taj način životinje nastanjene na drveću mnogo bliže Bogu. S druge strane gradeći kuće, za razliku od životinja, ljudi se, vremenom, suštinski otuđuju od prirode, koja je specifična vrsta Božijega samoobjavljivanja te specifičnog vida „objavljujućeg , govorenja živim bićima (hijerofanija). ${ }^{31}$

Ipak, tokom konverzacije između derviša i svrake od naročitog značaja za temu ovoga rada jeste posljednji dio spisa u kome se specificiraju posebne duhovno-religiozne vrijednosti nekoliko životinjskih vrsta iz ptičijega roda. Dakle, svraka predstavlja tașawwufskom i teološko-moralnom eksplikacijom slijedeće životinje: bijeloga sokola ${ }^{32}$, slavuja ${ }^{33}$, grlicu $^{34}$, papagaja ${ }^{35}$, sove $^{36}, \operatorname{rode}^{37}$,

${ }^{30}$ Zbog toga se, na ovome tragu, može navesti i slijedeći citat u kome svraka zbori dervišu slijedeće: „Kuće su gradili ljudi, a drveće je građevina svemilosnog Boga.” Prema F. Hadžibajrić, Zikr i iršad, str. 159.

${ }^{31}$ Na primjer: „A Gospodar tvoj objavljuje pčeli: 'Pravi sebi kuće u brdima i u dubovima i u onome što naprave ljudi, zatim, hrani se svakovrsnim plodovima, pa onda idi stazama Gospodara svoga, poslušno!' Iz utroba njihovih izlazi piće različitih boja koje je lijek ljudima. To je, uistinu, dokaz za ljude koji promišljaju.“ (Kur'an, sura „Pčela“-en-Naḥl, ajeti 68-69.)

${ }^{32}$ Car je za Svraku ujedno simbol 'Abd al-Qādir al-Ǵaylānīja, utemeljitelja qadariyskog tariqāta. U vezu sa bijelim sokolom se dovodi zbog jednog događaja iz svoga života, u kojem je ključnu ulogu imao njegov duhovni učitelj Ad-Dibbās. Naime, tijekom duhovnog odgoja 'Abd al-Qādirov učitelj Ad-Dibbās usnio je jedan neobičan san, u kojem je vidio sebe kako lovi sokola. Slijedeći dan je u tekiju došao 'Abd al-Qādir. Ad-Dibbās ga je pogledao oštro, nakon čega, kako se prenosi, kao da se srce Ġaylānīya raspuklo i rastvorilo. Doživio je stanje gazbe (duhovno privlačenje), te pao na tle izgubivši se. Od tada je prozvan 'Abd al-Qādir „Allāhov soko” ( $b \bar{a} z$ Allāh al-ašhab). I ovaj događaj očit jer pokazatelj specifičnog ekstatičnog iskustva, koje, više-manje, baštine sve starješine qadariyskog reda. Usp. Samir Beglerović, ,'Abd al-Qādir al-Ġaylānī: čovjek koji je rasplakao meleka smrti“, u: Znakovi vremena, svezak 12, br. 43-44., 2009., str. 29. S druge se pak strane, kada je u pitanju simbol bijeloga sokola, može reći da je duša poput sokola, jer se bijeli sokol najčešće vraća svome vlasniku. A u časnome Kur'anu se kaže: „A ti, o dušo smirena, vrati se Gospodaru svome zadovoljna, a i On tobom zadovoljan, pa uđi među robove Moje, i uđi u Džennet Moj!“ (Kur'an, 89:27-30) 
golubove $^{38}$, pupavca $^{39}$, i na koncu sâmu svraku ${ }^{40}$. Uporedo s time, opisuje njihove krijeposti i poroke te ukazuje na njihovu religioznost $\mathrm{i}$ odnos

${ }^{33}$ Slavuj je za svraku 'āšiq, a oni su u teologiji predstavljeni kao zaljubljenici i zbog toga nije neobično što biva stavljen znak jednakosti između 'āšiqa i slavuja. Naime, slavuj je simbol ljubavnika odnosno zaljubljenih diljem svijeta. Tașawwufsko-teologijski motreno, slavuj je, također, i simbol duše, koja je otjelovljenje čežnje za Vječitom Ljubavlju. Svaki zaljubljenik zbog svoje „opijenosti““ Božijom Ljepotom pjeva o Njoj, onoliko koliko može ,„pjevati““. Usp. Amina Šiljak-Jesenković, Odrazi ljubavnih mesnevija u stihovima bošnjačkih divanskih pjesnika, Orijentalni institut, Sarajevo, 2016., str. 260-272.

${ }^{34}$ Grlica je u traktatu predstavljena kao učač zikra. Zikr je zazivanje Imena Božijih, putem riječi, ili pak razmišljanjem o Njima. Postoje različiti oblici zikra: poput pojedinčnog ili pak skupnog. Moguće je zikr izgovarati tiho, glasnije, u sebi itd. Usp.: F. Hadžibajrić, Mali rječnik sufijsko-tarikatskih izraza, str. 217. Za ovu životinju može se posebno izdvojiti činjenica da je jako nježna i malena, te da opija svojom pjesmom zbog ljepote i blagosti koja proističe iz njenoga glasa. Zbog toga se, vjerojatno, u spisu podvlači ta simbolička jednakost između učača zikra s jedne i grlica sa druge strane. Usp. Amina Šiljak-Jesenković, Uvod u historiju i teoriju poetske forme mesnevija na turskom jeziku, str. 61.

${ }^{35}$ Svraka u tekstu odgovara da su papagaji 'ārifi. Navedeni arapski pojam označava osobu koja je spoznala duhovna gibanja u svijetu i životu, tj. iskustveno poznaje Božije tajne i u harmoniji sa njima usklađuje svoj način života. Usp.: F. Hadžibajrić, Mali rječnik sufijsko-tarikatskih izraza, str. 180.

${ }^{36}$ Sove su predstavljene kao vaizi, tj. propovjednici. Sova simbolizira mudrosti u mnogim drevnim kulturama. No, simbolički interpretiran njen govor u tradiciji muslimana nerijetko podsjeća na riječi: $H \bar{u} H \bar{u}$, što je zapravo poznato zazivanje Allahovoga Imena u tașawwufskoj praksi, koje označava Božiju apsolutnost,

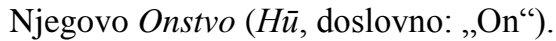

${ }^{37}$ U tekstu kosovskoga učenjaka, roda je simbol hadžije ili hodočasnika. U interpretativnoj tradiciji muslimana se, također, poistovjećuje sa hodočasnikom budući da je građena od bijeloga perja, te svojom fizionomijom asocira na hodočasnika u Meki, koji je obučen u ihrāme (dva komada bijele tkanine). Dapače, ona je i putnik, zbog čega na džamijama nerijetko gradi gnijezdo u minaretima, jednako kao što to čini u zvonicima. (Usp. Annemarie Schimmel, „Islam i čudesnosti stvorenja: Životinjsko carstvo“, u: Novi Muallim, svezak 15, br. 58., 2014., str. 50.)

${ }^{38}$ U Jašarovom spisu golubovi se izjednačavaju sa dervišima, tj. bivaju poistovjećeni sa sufijama. S druge pak strane, u svetoj povijesti islāma, u trenutku hiğre (prelaska iz Meke u Medinu časnog Poslanika i njegovog druga časnog Abū Bakira, 622. godine), blagoslovljeni Glasonoša i Abū Bakir sklonili su se prilikom potjere u jednu tamnu pećini na planini tawr. Golubica je, nakon što su se njih dvojica sklonila unutra, odmah načinila gnijezdo ispred pećine, a 
prema Bogu, Jednom i Jedinom. Dakle u ovome slučaju životinje tj. ptice, posjeduju jedno ili nekoliko lijepih svojstava (șifät ḥāmiidiyyah), a neka, opet, od njih su posebno efektno predstavljena u Jašarovom spisu.

pauk je izvezao mrežu točno preko pećinskog ulaza. Potjernici su odlučili ne ući u pećinu smatrajući da je paukova mreža, s obzirom na svoju veličinu, izvezena još prije rođenja Muḥammada, te, kako su zaključili, da je netko ulazio gnijezdo golubice bi bilo uništeno. Blagoslovljeni Glasonoša i Abū Bakr tijekom izlaska iz pećine pažljivo su pomaknuli gnijezdo trudeći se ne uništiti ga. (Usp. Martin Lings, Muhammed, život Vjerovjesnika islama zasnovan na najranijim izvorima, Conectum, Sarajevo, 2005., str. 163-164.) S ovim događajem se zbila mu'ğiza (čudo), jer je riječ o Božjoj intervenciji, koju su, u ovome slučaju, sprovele životinje: pauk i golubovi. (Usp.: Ibid.) Iz djelovanja i življenja golubova, očito se prepoznaje zajedništvo. Ta ćud se, na primjer, manifestira u njihovom instinktu dijeljenja hrane, jer golub nikada ne uzima hranu i ne leti sâm, već je dijeli s ostalim golubovima. Usp. Orhan Jašić, Bioetički problemi $u$ publikacijama Islamske zajednice u Bosni i Hercegovini od 1945 do 2012., Pergamena i Znanstveni centar izvrsnosti za integrativnu bioetiku, Zagreb, 2019., str. 134.

${ }^{39}$ Rehberi su osobe koji su vodiči u tarikatu tj. pokazuju pravovaljani put. To su osobe preko kojih se pristupa šayhu i sufijskim obredima. Usp.: Fejzulah Hadžibajrić, Mali rječnik sufijsko-tarikatskih izraza, str. 206. Da bi istaknuo značaj institucije rehbera Jašar njegovu funkciju pripisuje pupavcu, ptici, koja je spomenuta u Božijoj objavi. Hudhud (pupavac) služio je blagoslovljenom poslaniku Sulaymānu (Solomon) na njegovu dvoru te je imao zadaću svojevrsnog savjetnika, tj. onoga koji sakuplja i prenosi podatke, te ih predočava svome gospodaru. Ova ptica je pripovijedala blagoslovljenom Sulaymānu o svojim putešestvijima, o letu u daleku Sabu i o tamošnjoj kraljici, na osnovu čega se odigrala jedna od najznačajnijih epizoda u ljudskoj povijesti uopće, o čemu se u Kur'anu kaže: „Vidio sam da jedna žena njima vlada i da joj je svega i svačega dato, a ima i prijesto veličanstveni vidio sam da se i ona i narod njezin Suncu klanjaju, a ne Allahu - šejtan im je prikazao lijepim postupke njihove i od Pravoga puta ih odvratio, te oni ne umiju naći Pravi put pa da se klanju Allahu, koji izvodi ono što je skriveno na nebesima i u Zemlji i koji zna ono što krijete i ono što na javu iznosite. Allah je, nema boga osim Njega, Gospodar svega što postoji!". "Vidjet ćemo" - reče Sulejman - "da li govoriš istinu ili ne. Odnesi ovo moje pismo pa im ga baci, a onda se od njih malo izmakni i pogledaj šta će jedni drugima reći!" (Kur'an, 27: 23-28)

${ }_{40} U$ tekstu su ove ptice označene terminom kurnaz. Riječ je o pojmu sa dvostrukim značenjem, budući da može označavati, $s$ jedne strane mudre, a s druge prepredene ljude. No, u ovome slučaju njeno značenje se odnosi na pronicljivost tj. pametne osobe, jer svoje intelektualne $\mathrm{i}$ duhovne kapacitete koriste zaradi izgradnje i uzdizanja religioznog čovjeka tj. derviša. 
Ipak, jedino čovjek, kao krunsko Božije stvorenje (ahsān at-taqwīm) u prilici je objediniti doslovno sva pohvalna svojstva, odražena poglavito u Velikome svijetu ('ālam al-kabīr). Sâmim time, ljudsko biće nakon što ovlada unutar sebe, kao Malim svijetom ('älam aṣ-ṣağìr), temeljnim pohvalnim svojstvom određene životinje, tek tada postaje njen istinski zaštitnik i u izvanjskome svijetu. Analogno poziciji „namjesnika na Zemlji“" (halīfa fi al-arḍ) $)^{41}$, čin objedinjavanja svih pohvalnih svojstava predstavlja se kao obaveza svake osobe.

\section{OSVRT NA DJELO RAZGOVOR SA SVRAKOM}

Kao što je prethodno kazano, $u$ traktatu je pretežno riječ o pticama koje su zapravo produhovljenije u odnosu na svijet kopnenih životinja, te se svrstavaju u muslimanskoj tradiciji na viši stupanj prilikom gradiranja Bitka (ar. marātib al-wuğūd). Dapače kroz teșawwuf se govori o tzv. stupnjevima Bîtka, pri čemu svaki stupanj posjeduje svoju „unutarnju logiku” bivanja (osebujne svjetove, poseban način komuniciranja sa spoznavateljem itd.), te je svaki od njih međusobno snažno povezan i stoji u izravnoj vezi sa svim drugim stupnjevima, iz čega se upravo i razumijeva da i manifestirano i skriveno naprosto ukazuju na Jednoga. ${ }^{42}$

$\mathrm{U}$ ovome Jašarovom jezgrovitom $\mathrm{i}$ istovremeno inspirativnom spisu predstavljena je teocentrična percepcija odnosa prema svijetu općenito, ali i pticama posebno. Prilikom iščitavanja teksta, primjećuje se da su životinje stvorenja s tačno određenim zadaćama na ovome svijetu, kako zbiljskim tako i simboličkim. Naime, životinje pored vlastitog unutarnjeg smisla svoje egzistencije istovremeno služe ljudima i kao simboli za kosmos i više svjetove.

${ }^{41}$ „A kada Gospodar tvoj reče melecima: 'Ja ću na Zemlji namjesnika postaviti (innī ğă 'ilun fi al-arḍi halîfa)!' - oni rekoše: "Zar će Ti namjesnik biti onaj koji će na njoj nered činiti i krv proljevati? A mi Tebe veličamo i hvalimo i, kako Tebi dolikuje, štujemo." On reče: "Ja znam ono što vi ne znate." (Kur'an, 2:30)

${ }^{42}$ Usp. Abdullah Bošnjak, Gradacija Bitka, Sarajevo, Libris, 2003., str. 211-219. 
U ovoj raspravi izdvaja se svraka, koja je prvenstveno u ulozi učitelja. ${ }^{43}$ No, svraka je, također, i odgajatelj (ar. murabbli) budući da, kako smo prethodno objasnili, odgaja dušu pobožnog čovjeka-derviša. Ovo je zapravo jedan segment duhovnog putovanja (sayr as-sulūk) i proces aktiviranja organa nadosjetilne spoznaje: srca $\left(f u^{\prime} \bar{a} d\right)$, duše (nafs), duha (rūh), uma ('aql) i imaginacije (hayāl). ${ }^{44}$

Pored toga primjećuje se i da je akcent stavljen na komunikaciju ova dva bića. Samim time se u djelu Razgovor sa svrakom potcrtava i ukazuje na prijeko neophodni dijalog vrsta, budući da svraka, kao i druge spomenute ptice u Jašarovom kazivanju predstavljaju dio zajednice (umma), jednako kao i čovjek. ${ }^{45}$ Dijalogom između derviša i svrake naglašava se, između ostaloga, i spoznavanje suštine ljudskoga bića. Analogno tome esencija čovjeka, pa tako i hommo religiosusa, jest biti čovjek radi drugoga čovjeka tj. moralnoga odnosa prema njemu, ali i drugim stvorenjima. To je u biti istaknuto u svrakinom savjetu na kraju razgovora sa dervišom. ${ }^{46}$

\footnotetext{
${ }^{43}$ Ako se promotri sveta povijest islāma (ar. habar ar-rusul) može se uočiti da je jedna ptica podučavala prve ljude na zemlji ni manje ni više negoli ukopavanju mrtvih. Naime, nakon što je Adamov sin ubio brata Hābila, Qābil, pokajavši se za zlo koje je uradio, zapitao se što učiniti s bratovim truplom, na šta mu je Bog poslao znak u vidu ptice (Allah onda posla jednog gavrana da kopa po zemlji da bi mu pokazao kako da zakopa mrtvo tijelo brata svoga. "Teško meni!" - povika on - "zar i ja ne mogu, kao ovaj gavran, da zakopam mrtvo tijelo brata svoga"I pokaja se. (5:31)).

44 O organima duhovne spoznaje usp.: Rešid Hafizović, Spoznaja - prva vrijednost islama, Institut "Ibn Sina", Sarajevo, 2017., Također: usp. Rešid Hafizović, Islam u kulturnom identitetu Europe, Institut "Ibn Sina", Sarajevo, 2017., str. 9-51.

${ }^{45}$ Naime u časnome Kur'anu stoji: „Zar ne znaš da se i oni na nebesima i oni na Zemlji Allahu klanjaju, a i Sunce, i Mjesec, i zvijezde, i planine, i drveće, i životinje, i mnogi ljudi, a mnogi kaznu i zaslužuju. A koga Allah ponizi, niko ga ne može poštovanim učiniti; Allah ono što hoće radi." Kur'an (22:18)

${ }^{46}$ „Ja: - 'Daj mi kakav savjet. Svraka: - Zaštiti se dobrim, a odbaci nevaljalo, idi pravim putem, istopi grijehe, dobro očisti srce. Što vidiš, pokrij, a što ne vidiš, o tome ne govori. Ja: - Drago mi je što sam te sreo, koristile su mi tvoje mudre riječi. Hvala! Svraka: I meni je drago, hvala ti i želim ti uspjeh! Ostaj u ljubavi prema Bijelome sokolu! Diže se i odleti.“ Selim Sami Jašar, Razgovor sa svrakom, prema F. Hadžibajrić, Zikr i iršad str. 161.
} 
Jašarov pogled na svijet je, i te kako, izuzetno vrijedan i u suvremenom teološko moralnome diskursu, budući da se u ovoj poslanici primjećuje značaj harmonije između Velikog svijeta ('ālam al-kabīr) i Maloga svijeta ('ālam aṣ-șağìr). Shodno tome, navedeni sklad se zasniva primarno u razumijevanju i poštivanju drugog i drugačijeg, čemu, izvan svake sumnje, predstoji spoznaja (ma'rifa), i to sâmoga sebe, potom svijeta (drugih), te, u konačnici, i dragoga Boga (Stvoritelj svijeta). Taj segment življenja sa drugim i drugačijim, kao što su na primjer biljke i životinje odnosno ptice u ovome slučaju, izrazito je zapostavljen u životu suvremenog čovjeka, koji je prvenstveno pod utjecajem „elitne kulture“ utemeljene na potrošačkim i konzumerističkim vrijednostima egoistično orijentiran prema sebi samome tj. prema pojedincu. Samim time su životinje i biljke, kao i ostali ljudi, ništa drugo negoli interesno-tržišni predmeti zbog čega se, u posljedici, pojavljuje enormno uništavanje i iskorištavanje okolišnog i životinjskog blaga, te umjesto „razgovora“ zapravo dominira polemos i na njemu utemeljeno razaranje. Sukladno iščitavanju Jašareve poslanice primjećuje se da je za koegzistenciju sa animalnim svijetom čovjeku neophodan unutarnji sklad, koji se, opet, manifestira u krijeposnom načinu življenja.

$S$ obzirom na aktuelnu enormnu degradaciju biljnog i životinjskog svijeta, postavlja se pitanje: Da li je moguće govoriti o susretu Jašarovog teološko moralnog svetopogleda s bioetikom, koja se pojavila, između ostalog, i kao odgovor na destrukciju okoliša i životinjskog svijeta u dvadesetom stoljeću? Odmah se mogu detektirati primjetne diferencijacije, budući da je bioetika, kao grana etike, utemeljena na antropocentričnoj ili biocentričnoj slici svijeta, što je i razumljivo s obzirom na sâmu narav filozofije. S druge strane, Jašarov pristup je fundiran na teocentričnome pogledu na svijet, i sukladno tome mu je bioetički, dakle moderni te pristup koji se bazira dominantno na otklanjanju posljedica a ne i njihovih uzroka, suštinski stran. No, jednako tako, a bez obzira na vrlo izraženu epistemološku razliku, ipak je, smatramo, moguće govoriti o njihovome susretu u okviru integrativne bioetike. Razlog za to se nalazi u metodološkoj specifičnosti integrativne bioetike, jer se unutar nje odvija susret različitih disciplina pri čemu svaka od njih ponaosob zadržava svoju neovisnost uz „mogući“ 
zajednički pokušaj pronalaska rješenja za određeni teološko-moralni odnosno (bio)etički problem. Bez obzira na diferentna polazišta, ipak i navedeni teološko moralni, kao i brojni bioetički koncepti, teže realiziranju svojevrsne svijesti o realnosti zajedničke egzistencije svih stvorenja, a sâmim time imaju za krajnji cilj izvjesniji opstanak na ovome svijetu.

\section{ZAKLJUČAK}

Dakako, brojni su razlozi za pojavu bioetičkih problema, budući da bioetika u svome misaonome dijapazonu obuhvaća ponajprije odnos čovjeka i prirode, ali i čovjekov odnos prema zdravlju od začeća sve do smrti. Shodno širini znanstvenoga polja bioetike, u specifičnu vrstu bioetičkih problema nesumnjivo se može ubrojati i čovjekova relacija prema svijetu životinja. O tome su, pored filozofa, sociologa, ekologa, pisali, kako vidimo i teološki orijentirani muslimanski autori poput šejha Selima Samija Jašara sa Kosova.

Kako smo ranije istakli, Selim Sami Jašar je znatno prije pojave ozbiljnih bioetičkih rasprava, još u prvoj polovini dvadesetog stoljeća, na našim podnebljima pisao prvenstveno iz vjersko-teološkog ugla o svijetu životinja i njihovoj komunikaciji sa čovjekom. Njegov svjetopogled je epistemološki drugačiji od suvremenih razviđanja bioetičkih problema na način kako se ova problematika danas naročito tretira $u$ znanstvenoj literaturi. Upravo smo zbog toga smatrali vrijednim prezentirati i interpretirati Jašarov svjetonazor o svijetu životinja i njihovoj komunikaciji sa homo sapiensom na osnovu njegovog književnoteološkog djela Razgovor sa Svrakom.

Zbog povijesnog faktora pojave ovoga djela, tj. perioda prije nastupa Drugog svjetskoga rata, smatrali smo da bi bilo dobro $\mathrm{u}$ današnjemu vremenu svojevrsne postkulture skrenuti pozornost na Jašarovu teološko-moralnu refleksiju animalnoga svijeta, koja je u suprotnosti sa mnogobrojnim etičkim aksiomima visoke moderne odnosno postkulture, budući da je postulirana na duhovno religioznim temeljima na osnovu kojih se i druga bića motre kao stvorenja kreirana od Jednog i Jedinog Stvoritelja. 


\section{LITERATURA}

Abdullah Bošnjak, Gradacija Bitka, Sarajevo, Libris, 2003.

Al-Ğurğānī, Kitāb at-ta 'rīfāt, u zbirci poslanica: Mağmū'a al-kutub, objavljenoj u Kairu, al-maṭba'a al-ḥamīdiyy al-mișriyya, 1321

Amina Šiljak-Jesenković, Odrazi ljubavnih mesnevija u stihovima bošnjačkih divanskih pjesnika, Orijentalni institut, Sarajevo, 2016.

Amina Šiljak-Jesenković, Uvod u historiju i teoriju poetske forme mesnevija na turskom jeziku, Orijentalni institut, Sarajevo, 2017.

Amir Orman, „Pedeset godina od preseljenja šejh hadži Selim Sami jašara“ Šebi arus, Sarajevo 2000.

Annemarie Schimmel, „Islam i čudesnosti stvorenja: Životinjsko carstvo“, u: Novi Muallim svezak 15, br. 58, 2014.

Brandon Zimmerman, „Does Plotinus present a Philosophical Account of Creation?", u: The Review of Metaphysics, svezak 67, br. 1, 2013.

Fehim Nametak, Pojmovnik divanske i tesavvufske književnosti, Orijentalni institut u Sarajevu, Sarajevo, 2007.

Fejzulah Hadžibajrić, »Mali rječnik sufijsko-tarikatskih izraza«, u: Mustafa Cerić (ur.), Tesawwuf, islamska mistika, Zagrebačka džamija, Zagreb, 1989.

Fejzulah Hadžibajrić, Zikr i iršad u: Mustafa Cerić (ur.), Tesawwuf, islamska mistika, Zagrebačka džamija, Zagreb, 1989.

Ferhat Grguri, „Hadži hafiz Sabit Zaimi efendi“, u: Glasnik Vrhovnog islamskog starješinstva u Socijalističkoj Federativnoj Republici Jugoslaviji, svezak 6, br. 39, 1976.

Gerhard Böwering, „The Concept of Time in Islam“, u: Proceedings of the American Philosophical Society, svezak 141, br. 1, 1997.

Ibn 'Arabī, al-Futūhāt al-makkiyya, Bejrut, Dār al-kutub al-'ilmiyya, 1998., poglavlje 48., cjelina: „Mas'ala dawriyya min hād̄ā al-bāb wa hādihi șūretuhā, tom I.

Kur'an, Orijentalni institut Sarajevo, Sarajevo, 1977. (preveo: Besim Korkut)

Martin Lings, Muhammed, život Vjerovjesnika islama zasnovan na najranijim izvorima, Conectum, Sarajevo, 2005.

Mohamed Haj Yousuf, Ibn 'Arabî - Time and Cosmology, London - New York, Routledge, 2008.

Orhan Jašić, Bioetički problemi u publikacijama Islamske zajednice u Bosni $i$ Hercegovini od 1945 do 2012., Pergamena i Znanstveni centar izvrsnosti za integrativnu bioetiku, Zagreb, 2019.

Plotin, Eneade, Beograd, NIRO „Književne novine“, 1984., III. 
Rešid Hafizović, Islam u kulturnom identitetu Europe, Institut "Ibn Sina", Sarajevo, 2017.

Rešid Hafizović, Spoznaja - prva vrijednost islama, Institut "Ibn Sina", Sarajevo, 2016.

Rešid Hafizović, Temeljni tokovi sufizma, 'Bemust', Zenica, 1999.

Samir Beglerović, „Abd al-Qādir al-Ġaylānī: čovjek koji je rasplakao meleka smrti“, u: Znakovi vremena, svezak 12, br. 43-44., 2009.

Samir Beglerović, „Crtice iz života hadži šejha Fejzulaha efendije Hadžibajrića“, u: Znakovi vremena, svezak 7, br. 25, 2004.

Samir Beglerović, Tesavvuf Bosne u vidicima Fejzulaha Hadžibajrića: Vjerski $i$ kulturni razvoj bosanskih muslimana u prvoj polovini XX stoljeća, Sarajevo, „Bookline“, 2014.

Sead Halilagić, „Hadži Selim Sami ef. (Uz 40-godišnjicu smrti)“, Šebi arus, Sarajevo 91.

Selim Sami Jašar, Razgovor sa svrakom, prema Fejzulah Hadžibajrić, Zikr i iršad u: Mustafa Cerić (ur.), Tesawwuf, islamska mistika, Zagrebačka džamija, Zagreb, 1989.

Selim Sami Jašar, Tuhfa - Dar -, Vatan, Malmö, 1996.

William H. Desmonde, „The Ritual Origin of Plato's Dialogues: A Study of Argumentation and Conversation among Intellectuals", American Imago, svezak 17, br. 4, zima 1960.

\title{
SAMIR BEGLEROVIĆ
}

University of Sarajevo, Faculty of Islamic Studies ORHAN JAŠIĆ

University of Sarajevo, Faculty of Islamic Studies / University of Tuzla, Faculty of Philosophy

\section{THEOLOGICAL AND ETHICAL ISSUES IN THE WORK CONVERSATION WITH THE MAGPIE BY SELIM SAMI JA ̌̌SAR}

\begin{abstract}
The first part of the paper briefly presents the biography of the theologian, sufi and muderris (Professor) Selim Sami Jašar from Vučitrn (Kosovo). Although he is the author of several works in the field of theology, in this paper we have reflected on his allegorical tale Conversation with the
\end{abstract}


Magpie, which was translated into our language by Professor Fejzulah Hadžibajrić. In this tale, in the form of a dialogue, a Dervish (in this case author Selim Sami Jašar himself) talks with a magpie, primarily about the topics of tașawwuf (sufism) and Islamic dogmatics ('Aqa'id), but also about the topics belonging to the field of theology of moral ('Ilm al-Ahläq). Particular attention is drawn to the presentation of the symbolism of the animal world, bios, whose essence is examined from the mentioned perspectives. Among other things, the paper emphasizes the historical context of this symbolical tale because it was written in the first half of the twentieth century when not too much attention was given in the West to the zooethical and fitoethical issues.

Keywords: Selim Jašar, tașawwuf, theology of moral ('Ilm al-Ahlāq), magpie, ethics

Primljeno: 1.12.2019.

Prihvaćeno: 29.12.2019. 